\title{
Sustainability Management Program for Industries- A Case Study
}

\author{
Alwin Long Su Weng ${ }^{1}$, Samson Mekbib Atnaw ${ }^{2, *}$, Roziah Binti Zailan ${ }^{2}$ and Muhamad Muhtazam Noor Din ${ }^{3}$ \\ ${ }^{1}$ Universiti Kebangsaan Malaysia LESTARI Institute for Environment \& Development \\ ${ }^{2}$ Universiti Malaysia Pahang, Faculty of Engineering Technology, Gambang, Pahang, 26300, Malaysia \\ ${ }^{3}$ Malaysian Green Technology Corporation, Green-Living-Energy Services
}

\begin{abstract}
This research studied the effectiveness of Sustainability Management Program in improving production efficiency of the manufacturing site with verified result using the regression analysis. For this study, a dairy manufacturing industry located in Malaysia was selected and major energy consuming equipment in the industry plant were identified. Sustainability Management Program (SMP) was carried out for three years and energy consumption and product has improved regression coefficients of 0.625 in 2013, 0.826 in 2014, and 0.878 in 2015 as the manufacturing site becomes more energy efficient. This suggests that the energy management should be carried out in a continuous manner with energy management team responsible for energy saving practices.
\end{abstract}

\section{Introduction}

Global statistics revealed that industrial energy consumption accounts for about $40 \%$ of generated electricity [1, 2]. Increasing technological development over the years has therefore attracted complex designs for energy consuming equipment. Miniaturization, microfabrication of devices and systems are somewhat as a result of a rise in the use of energy saving techniques. However, efficiency improvement technique as a means of generating more economic output with less energy as input is key to achieving a sustainable development [3]. Utilization index of energy supplied to a system cannot be $100 \%$, thereby obeying the third law of thermodynamics. Energy consumption by industrial systems is rather a form of conversion from its initial form to another [4]. An efficient management of how this transformation takes place in an industrial system is therefore of necessity and it must have continuity in order to be sustainable. Organisational structural planning of energy saving policy remains principal to its growth [5]. Regardless of a cost-benefit analysis and value addition of energy, increasing energy cost in industrial systems remains detrimental to process output cost and competitiveness $[6,7]$.

Over the years, research has been narrowed to design and development of low-energy consuming and conserving devices [8, 13]. Recent microprocessors built in industrial systems devices allow for power management through dynamic voltage scaling (DVS) thereby reducing voltage consumption and increasing power savings [13]. Limiting the energy dissipation in the form of heat, power sensors for heavy duty machineries are receiving substantial attention in research $[9,10,14]$.

Energy management is a process for an efficient system operation. However many of such processes focus upon piece meal projects related to devices or technologies with little or no verification to confirm the effectiveness of the project. Hence it birthed forth a Sustainability Management Program (SMP), which can be carried out in cycle as shown in Fig. 1. It can best be viewed from the systems approach with components having a ripple effect on the system when perturbations occur. An energy management strategy seeks to optimize and obtain a balance between the demand and supply in system operation [15-18]. Market mechanisms could therefore be critically optimized using systems dynamics principles with feedbacks and patterns carefully studied [15, 19, 20-22]. This paper, studied the effectiveness of Sustainability Management Program in improving production efficiency of a manufacturing site located in Malaysia with verified result using the regression analysis.

\footnotetext{
Corresponding author: mekbibsams@ump.edu.my
} 


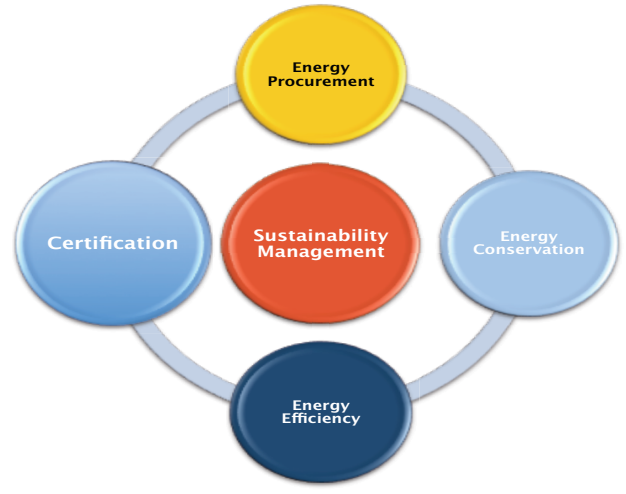

Fig. 1. Sustainability management program [23]
The energy matrix is one of the cruxes of an energy management model that levels and organizational action steps across each level. A typical example is as shown in Table 1. Energy policy, systems organization, training, performance management, communication and investment form the primal of energy management matrix. Each level has its standards to meet and best used, as a benchmarking to what it should be as the management system improves. By deploying the energy management matrix, organization is able to set a baseline to where their current status is and how they may improve in building a more resilient if not a sustainable energy management corporation.

Table 1. Energy management matrix

\begin{tabular}{|c|c|c|c|c|c|c|}
\hline Level & Energy Policy & Organising & Training & $\begin{array}{l}\text { Performance } \\
\text { Measurement }\end{array}$ & Communication & Investment \\
\hline 4 & $\begin{array}{c}\text { Energy Policy, } \\
\text { Action Plan and } \\
\text { regular review } \\
\text { have active } \\
\text { commitment of } \\
\text { Senior } \\
\text { Management Team } \\
\text { and aligned to SDP } \\
\end{array}$ & $\begin{array}{l}\text { Fully integrated into } \\
\text { management } \\
\text { structure with clear } \\
\text { accountability for } \\
\text { energy consumption }\end{array}$ & $\begin{array}{l}\text { Appropriate and } \\
\text { comprehensive } \\
\text { training tailored to } \\
\text { identified needs, } \\
\text { with evaluation for } \\
\text { all school } \\
\text { stakeholders }\end{array}$ & $\begin{array}{c}\text { Comprehensive } \\
\text { performance } \\
\text { measurement against } \\
\text { targets with effective } \\
\text { management } \\
\text { reporting }\end{array}$ & $\begin{array}{l}\text { Extensive } \\
\text { communication of } \\
\text { energy issues within } \\
\text { and outside of school } \\
\text { to wider school } \\
\text { stakeholders }\end{array}$ & $\begin{array}{c}\text { Resources routinely } \\
\text { committed/sourced } \\
\text { to support energy } \\
\text { efficiency in school } \\
\text { supporting } \\
\text { objectives }\end{array}$ \\
\hline 3 & $\begin{array}{c}\text { Formal Policy but } \\
\text { no active } \\
\text { commitment from } \\
\text { Senior } \\
\text { Management Team }\end{array}$ & $\begin{array}{c}\text { Clear line } \\
\text { management } \\
\text { accountability for } \\
\text { consumption and } \\
\text { responsibility for } \\
\text { improvement } \\
\end{array}$ & $\begin{array}{l}\text { Energy training } \\
\text { targeted at relevant } \\
\text { staff following } \\
\text { training needs } \\
\text { analysis }\end{array}$ & $\begin{array}{l}\text { Weekly performance } \\
\text { measurement for } \\
\text { each process, unit, or } \\
\text { building }\end{array}$ & $\begin{array}{l}\text { Regular staff briefings, } \\
\text { assemblies, } \\
\text { performance reporting } \\
\text { and energy promotion }\end{array}$ & $\begin{array}{l}\text { Same appraisal } \\
\text { criteria used as for } \\
\text { other cost } \\
\text { reduction projects }\end{array}$ \\
\hline 2 & Un-adpoted Policy & $\begin{array}{l}\text { Some delegation of } \\
\text { responsibility but } \\
\text { line management } \\
\text { and authority } \\
\text { unclear }\end{array}$ & $\begin{array}{l}\text { Ad-Hoc training for } \\
\text { selected people as } \\
\text { required }\end{array}$ & $\begin{array}{l}\text { Monthly monitoring by } \\
\text { fuel type of use and } \\
\text { cost }\end{array}$ & $\begin{array}{l}\text { Some use of school } \\
\text { communication } \\
\text { mechanisms to } \\
\text { promote energy } \\
\text { efficiency }\end{array}$ & $\begin{array}{l}\text { Low or medium } \\
\text { cost measures } \\
\text { considered if short } \\
\text { payback period }\end{array}$ \\
\hline 1 & $\begin{array}{l}\text { An unwritten set } \\
\text { of guidelines }\end{array}$ & $\begin{array}{l}\text { Informal, mostly } \\
\text { focused on energy } \\
\text { supply and billing }\end{array}$ & $\begin{array}{l}\text { Technical staff } \\
\text { occasionally attend } \\
\text { \$ecialist courses }\end{array}$ & Invoice checking only & $\begin{array}{l}\text { Ad-Hoc informal } \\
\text { contacts used to } \\
\text { promote energy } \\
\text { efficiency e.g. one off } \\
\text { assembly/meeting }\end{array}$ & $\begin{array}{l}\text { Only low or no cost } \\
\text { measures taken } \\
\text { e.g. 'switch off' } \\
\text { posters }\end{array}$ \\
\hline 0 & $\begin{array}{l}\text { No explicit Energy } \\
\text { Policy }\end{array}$ & $\begin{array}{l}\text { No delegation of } \\
\text { responsibility for } \\
\text { managing energy }\end{array}$ & $\begin{array}{l}\text { No energy related } \\
\text { staff training } \\
\text { attended }\end{array}$ & $\begin{array}{l}\text { No measurement of } \\
\text { energy costs or } \\
\text { consumption }\end{array}$ & $\begin{array}{l}\text { No communication or } \\
\text { promotion of energy } \\
\text { issues }\end{array}$ & $\begin{array}{l}\text { No investment in } \\
\text { mproving energy } \\
\text { efficiency by the } \\
\text { school }\end{array}$ \\
\hline
\end{tabular}

\section{Materials and Methods}

Industrial energy management is factor dependent. Among the factors which governs its success are geographical locations and organizational energy policy. Current pracitce of chosen companies were investigated thorugh an energy auditting process. Achieving a sustainable energy development involves constituting committes accountable for its success. Two committees were constituted: the energy committee and the energy accounting centre committee. Organsisational strucutre to ensure both vertical and horizontal flow of information was developed. Job description of each committee was developed.

\subsection{Sustainable Energy Savings using AEMAS framework}

One of the primal factors to continuous availability of energy systems is the development of energy policy interventions [15]. One of the essential of considerable energy savings is the energy matrix that was devised under the ASEAN Energy Management Scheme (AEMAS).

\subsection{Energy procurement: electricity and natural gas usage breakdown}

In this process, energy costs associated with energy consumption for production were evaluated. At the point of research, two major sources of energy were procured 
namely electricity and natural gas. Back in 2012 the electricity cost in Malaysia was at RM 0.304 per $\mathrm{kWh}$ during peak period, RM 0.187 during off-peak period and RM 27.70 for maximum demand with a blended rate of $\mathrm{RM} 0.32$ per $\mathrm{kWh}$. On the other hand average natural gas price for industrial consumption in Malaysia was approximately RM 16.07 for one million British Thermal Unit (MMBTU). Hence selecting the right energy for each application especially for heating ventilation and air conditioning (HVAC) systems are critical towards the company's profitability. Shown in Fig. 2 and 3 are the energy cost movement across four years and how it would have impacted production costs [24].

Electricity costs alone increased by $15 \%$ from an average of RM0.32 for each kilowatt-hour to RM0.38 kilowatt-hour. The natural gas cost on the other hand increased by astounding 57\% from RM16.07 for one MMBTU to RM26.00 for one MMBTU. The impact was managed through the Sustainability Management Program with results presented at the end of the paper.

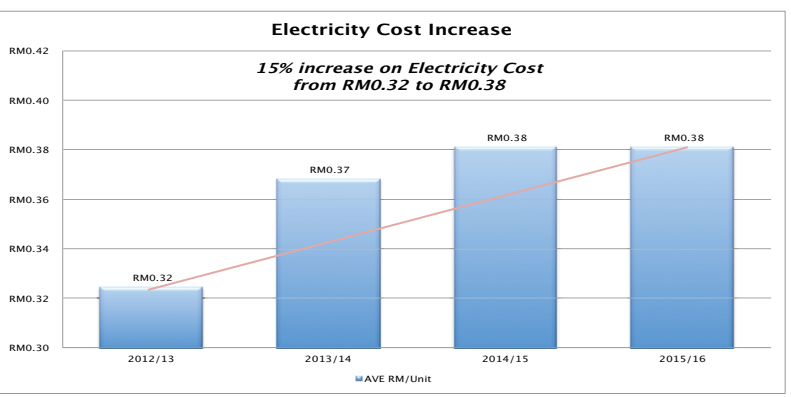

Fig. 2. Electricity cost fluctuation for 2012, 2013, 2014 and 2015 [24]

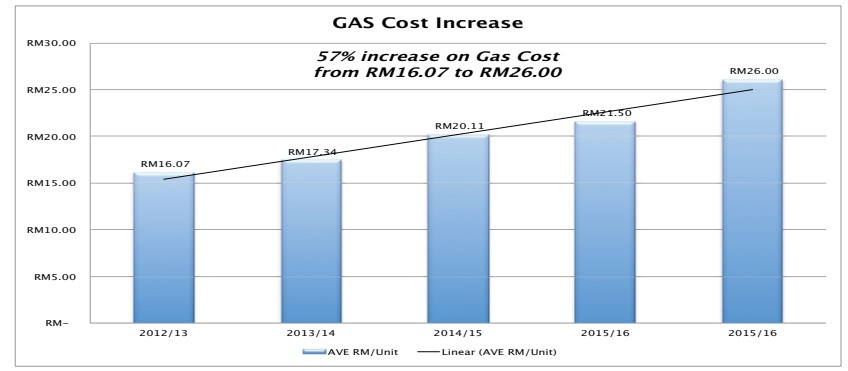

Fig. 3. Natural gas cost fluctuation for 2012, 2013, 2014 and 2015 [2]

\subsection{Energy conservation through empower energy committee}

Sustainability in most energy management activity is seen as a challenge. Two main challenges faced were (1)

Commitment from top management (2) Measurement and verification on savings achieved.

The paper covers the establishment of a Sustainability Management committee that is headed by the highest management member in the plant. Energy committee was constituted with three management levels with each level having predefined job descriptions as shown in Fig. 4. Thus everyone shall have detailed information of what is required in the role they were appointed governed under the periodic meetings to keep track with progress.

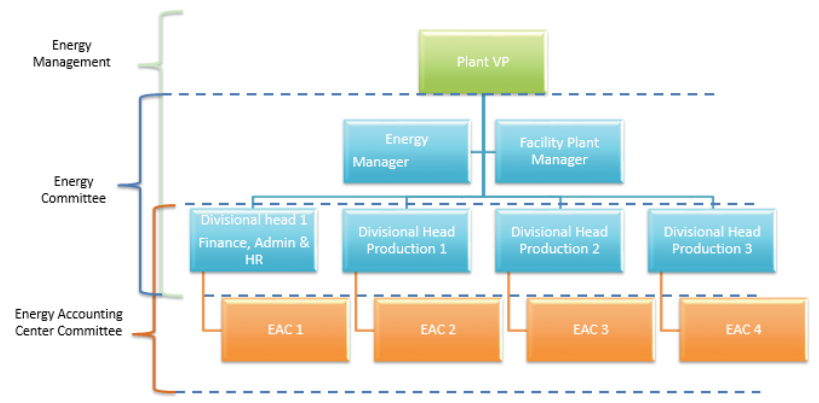

Fig. 4. Energy committee management levels

Each committee was saddled with predefined responsibilities as below:

A. Energy Management (EM)

a. Meet once to twice a year

b. Decision maker for strategic matters

c. Setting Target, approve plans, budget

d. Center for approvals

B. Energy Committee (EC)

a. Meet once a month (Technical Team)

b. Carry out Plan to meet overall target

c. Setting Target for EAC to meet overall target

d. Update management on Measurement \& Verification (M\&V)

C. Energy Accounting Center (EAC) Committee

a. Meet daily or weekly with EAC head

b. Carry out Plan to meet overall target

c. Measure \& verify savings

d. Update EC on Measurement \& Verification (M\&V)

e. Identify savings opportunity

\section{Results and Discussion}




\subsection{Energy efficiency by conducting energy audit}

The success of implementing new ideas and innovations depends on the outcome of analysis of the current practice. Most organizations are often faced with challenges concomitant to the formulation of energy performance indicators, integrating energy management and technology [16, 20-22]. Organizational energy audit requires selection of a target facility and actions plan developed around it before implementation. Energy generation and outlets of consumptions were selected and an audit were carried out in this paper. Having the Certified Energy Manager reporting directly to the top management helps bring energy management as a priority, working alongside with the grass roots personnel in the $\mathrm{EAC}$

\subsection{Identification of high energy consuming equipment}

The manufacturing plant performs its daily operations on two energy sources; the national grid and natural gas. The EAC Managers will brief their committee on a daily basis to determine the production areas where savings can be found and later raise the proposal to the energy committee on their monthly meeting.

Centralized facilities equipment such as the heating, ventilation and air conditioning (HVAC) equipment with high-energy consumption were identified and energy audit conducted on them. The areas identified are as below;

Heat, Ventilation and Air Conditioning (HVAC) systems
a. Condenser Water System
b. Chilled Water Pump System
c. Cooling Tower Fans Optimization

Unit Operation systems
a. Boiler Optimization
b. Air Compressor System
c. Ammonia Compressor System
d. Cooling Water Plant System
e. Cooling Tower Fans Optimization
f. Chiller Pump System

Value system designs were conducted on the selected Change of Organization Investment criteria by looking at projects with payback below 3 years.

Energy consumption rate to production follows a linear relationship. The plot shown in Fig. 5, 6 and 7 reveal an $\mathrm{R}^{2}$ values of 0.62458 in $2012 / 2013,0.82654$ in $2013 / 14$, and 0.87833 in $2015 / 16$, respectively. The regression model serves as a good indicator on energy efficiency impact across the three years period and better predictor of energy consumption for the manufacturing plant in the future with the regression Equation 1.

$Y=56.886 x+836938$

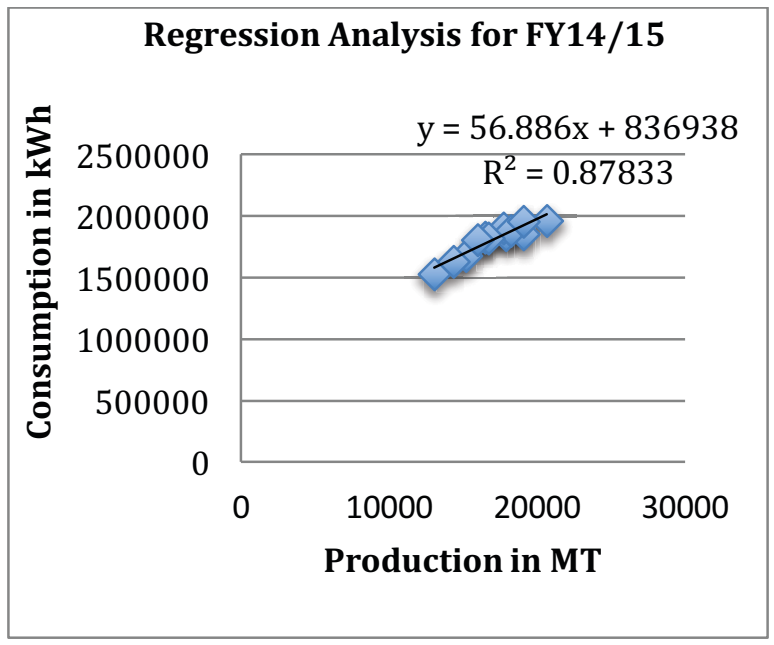

Fig. 5. Regression plot of energy consumption on energy production (FY14/15)

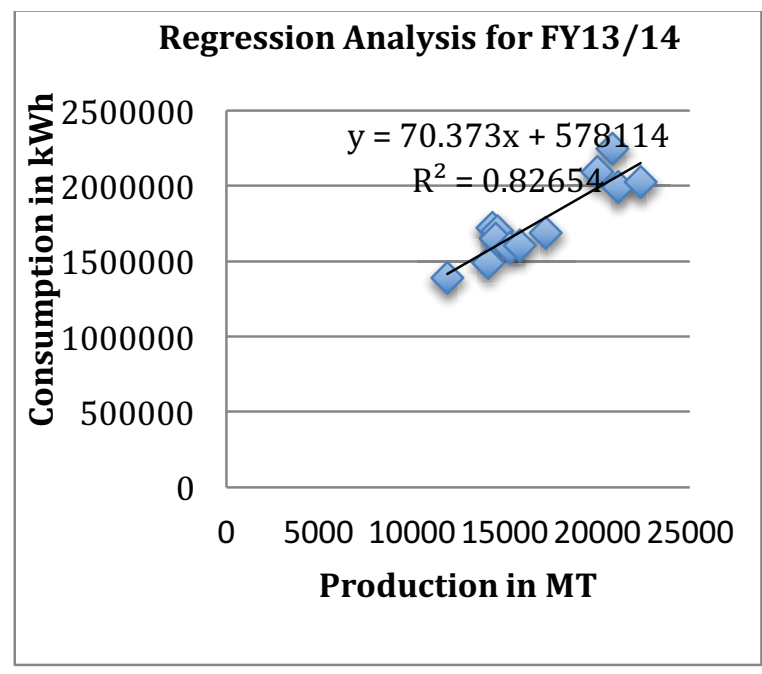

Fig. 6. Regression plot of energy consumption on energy production (FY13/14) 


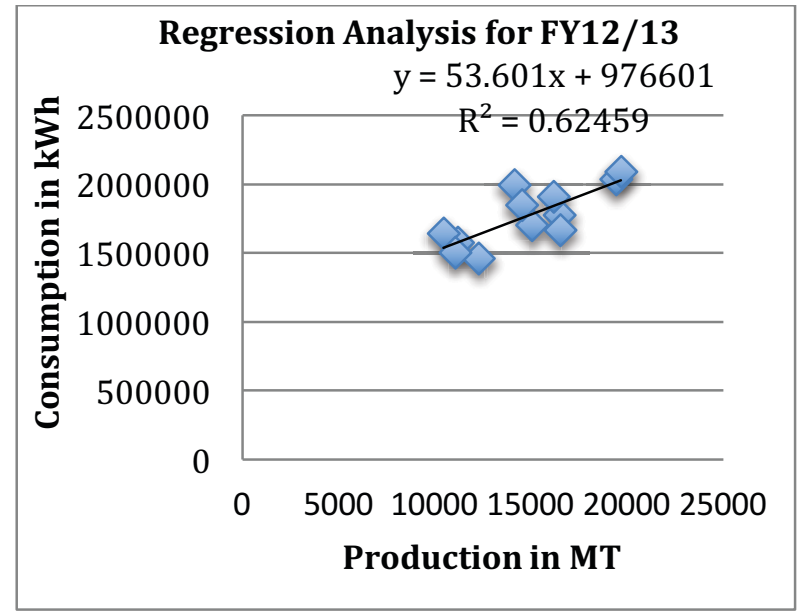

Fig. 7. Regression plot of energy consumption on energy production (FY12/13)

\section{Conclusion}

One of the salient ways by which energy is wasted is through its mismanagement. Equipment not needed are often left to run at no load, electric bulbs not needed are left on throughout the day, offices which could be served by one air conditioners are supplied with two and lots more. Identification of energy consuming equipment is therefore needful. This can only be achieved through energy audit of the system. Data collected for this project were subjected to statistical analysis and a regression model developed to this effect.

For the two companies selected, regression models developed has energy production successfully predict the energy consumed. A forecast of energy production from the base period was determined and compared with the achieved production per year. Considerable energy savings was recorded with an energy management framework developed for critical subsystems identified to consume energy the most within the system as a whole.

\section{Acknowledgement}

This paper was supported by the Internal Grant of the University Malaysia Pahang (RDU160393) and Fundamental Research Grant Scheme (FRGS) grant of Malaysian Ministry of Higher Education (RDU140109).

\section{References}

[1] P.A. Adedeji, O.A. Olalere, O.A. Adebimpe, S.O. Olunusi, Int. J. Eng. Sci. 3, 73-79 (2014)

[2] A. McKane, Ind. Energ. Manage. (2007)

[3] D. Viadmir, The Netherlands, ERSCP-EMSU. (2010)

[4] K. Vikhorev, R. Greenough, N. Brown, J. Cleaner Product. 1-11 (2012)

[5] O.A. Olalere, P.A. Adedeji, O.A. Adebimpe, B. Olayiwola, Int. J. Eng. Sci. 3, 55-62 (2014)

[6] ECON. Ministry of Industry, Employment and Communications. (2003)

[7] P. Thollander, J. Palm, New York: Spinger. (2013)

[8] F. Douglis, P. Krishnan, Computing Systems. 8, 381-413 (1995)

[9] F. Jason, M. Satyanarayanan, 17th Symposium on Operating Systems Principles. (2001)

[10] T. Halfhill, Microprocessor. (2000)

[11] T. Heath, 11th International Conference on Parallel Architectures and Compilation Technques. (2002)

[12] R.A. Lebeck, X. Fan, H. Zeng, S.C. Ellis, 9th International Conference on Architectural Support for Programming Languages and Operating Systems (ASPLOS IX). (2000)

[13] R. Bianchini, R. Rajamony, NJ: DARPA. (2003)

[14] A. Oumer, S.M. Atnaw, J.K. Cheng, L. Singh, Mater. Sci. Eng. (2016)

[15] P. Palensky, D. Dietrich, IEEE Transac. Ind. Informatics. 7, 381-389 (2011)

[16] S.O. Oyedepo, Energ. Sustainab. Society. 2, 1-17 (2012)

[17] T.Y. Chiu, S.L. Lo, Y.Y. Tsai, Energies. 5, 53245339 (2012)

[18]O. Fuji, Busan Korea, International Electrical Vehicle Symposium. (2002)

[19] J. Moreno, M.E. Ortuzar, J.W. Dixon, IEEE Transac. Ind. Electronics. 53, 614-624 (2006)

[20] V. Sharma, U. Mrkherji, V. Joseph, S. Gupta, IEEE. 1-23 (2008)

[21] Siemens. Energy mangment and energy optimization in the process industry. Germany: Siemens. (2011)

[22] M. Weiser, B. Welch, A. Demers, S. Shenker, 1st Symposium on Operating System Design and Implementation. (1994)

[23] M.M. Williansen, Professional Safety. (2005)

[24] Tenaga Nasional Pricing \& Tariffs (2016), Retrived from http://www.mida.gov.my/env3/uplo ads/images/Tariff_Rate_Final_01.Jan.2014.pdf 